\title{
Effects of decreased estradiol-17 $\beta$ on the serum and anterior pituitary IGF-I system in pigs
}

\author{
C K Hilleson-Gayne and J A Clapper
}

South Dakota State University, Department of Animal and Range Sciences, Box 2170 Brookings, South Dakota 57007, USA

(Requests for offprints should be addressed to J A Clapper; Email: Jeffrey.Clapper@sdstate.edu.)

\begin{abstract}
To further delineate the role of estradiol in the IGF system an experiment was conducted to determine the dosage of the aromatase inhibitor, anastrozole, needed to decreases serum concentrations of estradiol-17 $\beta$ (E2) in maturing boars. A second experiment was conducted to determine if administration of anastrozole to growing boars decreased serum concentrations of E2 and affected components of the serum and anterior pituitary gland (AP) IGF system vs untreated boars and barrows. In Experiment 1, 12 crossbred boars (292 days, $158 \mathrm{~kg}$ ) were administered either 0 , 1 or $10 \mathrm{mg} /$ day anastrozole ( $n=4 /$ group) beginning on day 1. Blood samples were collected every 7-14 days. Mean serum concentrations of E2 were decreased $(P<0 \cdot 05)$ in the $10 \mathrm{mg}$ group vs the 0 and $1 \mathrm{mg}$ groups by day 36; however, no difference $(P>0 \cdot 05)$ existed between the 0 and $1 \mathrm{mg}$ groups. In Experiment 2, 24 crossbred boars and 12 barrows (101 days, $44 \mathrm{~kg}$ ) were stratified by litter to one of three treatment groups $(n=12)$ : boars administered $10 \mathrm{mg} /$ day anastrozole, boars administered $0 \mathrm{mg} /$ day, and barrows administered $0 \mathrm{mg} /$ day. Blood samples were collected and pigs were weighed on day 0 and every 14 days thereafter, then killed on day 84 when blood and APs were collected. The $10 \mathrm{mg} /$ day pigs were
\end{abstract}

fed the anastrozole-amended diet beginning on day 1. Mean serum concentrations of E2 did not differ $(P>0.05)$ between the $10 \mathrm{mg} /$ day pigs and $0 \mathrm{mg} /$ day pigs on day 0 ; however, on day 15 through to 84 mean serum concentrations of $\mathrm{E} 2$ were greater $(P<0 \cdot 05)$ in $0 \mathrm{mg} /$ day pigs than in the $10 \mathrm{mg} /$ day pigs. Mean percentage increase in serum concentrations of IGF-I was greater $(P<0.05)$ in untreated boars than anastrozole-treated boars and barrows from day 58 through to 84 . Mean percentage of basal IGF-I increased $(P<0 \cdot 05)$ from day 29 through to 84 in untreated boars. Mean relative amounts of AP IGFbinding protein (IGFBP)-2 and -5 were less $(P<0 \cdot 01)$ in $10 \mathrm{mg} /$ day pigs than in the $0 \mathrm{mg}$ /day pigs, but each was greater $(P<0 \cdot 01)$ than in barrows administered $0 \mathrm{mg} /$ day. These results indicate anastrozole administered at a dosage of $10 \mathrm{mg}$ /day suppresses serum concentrations of E2 in pigs. Administration of anastrozole to boars reduced the percentage increase in serum concentrations of IGF-I and relative amounts of AP IGFBP-2 and -5 . These data further support a role for $\mathrm{E} 2$ in regulating components of the IGF system in pigs.

Journal of Endocrinology (2005) 187, 369-378

\section{Introduction}

It is well established that boars grow faster and more efficiently than gilts or barrows (Dunshea et al. 1993, Owens et al. 1999, Clapper et al. 2000). Growth differences among boars, barrows and gilts may be due to the differences in circulating concentrations of estradiol-17 $\beta$ (E2) and insulin-like growth factor-I (IGF-I). Administration of estrogenic compounds (De Wilde \& Lauwers 1984) or IGF-I (Klindt et al. 1998) has been shown to increase lean gain and efficiency of growth in swine. Clapper et al. (2000) found that mean serum concentrations of E2 were greater in boars than in gilts and increased with age in boars. Boars have also been found to have greater circulating concentrations of IGF-I than gilts or barrows (Dunshea et al. 1993, Owens et al. 1999,
Clapper et al. 2000). Administration of E2 implants has been reported to increase circulating concentrations of IGF-I in barrows (Rempel \& Clapper 2002), steers (Enright et al. 1990, Hays et al. 1995), and ovariectomized ewes (Clapper et al. 1998). Thus, E2 may mediate its growth-promoting effects through increases in circulating concentrations of IGF-I.

Estradiol has been shown to affect circulating components of the IGF-I system in pigs. Insulin-like growth factor binding proteins (IGFBPs), which are part of the IGF-I system, can regulate IGF actions by stimulating or inhibiting IGF-I activity (Zapf 1995). Previous research has demonstrated that mean serum concentrations of E2 and IGF-I and mean relative amounts of both forms of IGFBP-3 and the $28 \mathrm{kDa}$ IGFBP-4 were greater in boars than barrows and gilts, and mean relative amounts of 
serum IGFBP-2 were greater in boars and barrows than gilts (Clapper et al. 2000). Administration of E2 implants increased mean serum concentrations of IGF-I, and relative amounts of the $41 \mathrm{kDa}$ IGFBP-3 in barrows (Rempel \& Clapper 2002). Barrows implanted with E2 also had greater relative amounts of serum IGFBP-2 vs boars, although mean serum concentrations of IGF-I were greater in boars than in implanted or unimplanted barrows (Rempel \& Clapper 2002).

Estradiol has been found to affect components of the porcine anterior pituitary gland (AP) IGF-I system as well. Rempel \& Clapper (2002) found E2-implanted barrows had greater AP concentrations of IGF-I compared with boars and unimplanted barrows. However, boars still had greater relative amounts of AP IGFBP- 2 and -5 vs implanted and unimplanted barrows (Rempel \& Clapper 2002). Because both estradiol and testosterone were increasing in the boars during this time it was not possible to determine which steroid(s) and/or gonadal factors might be responsible for the increase in relative amounts of AP IGFBP-2 and -5 .

Estradiol is synthesized from androgens by the aromatase enzyme (Simpson et al. 1994). Anastrozole is a nonsteroidal aromatase inhibitor that prevents the aromatase enzyme from synthesizing E2 from androgens (Mauras et al. 2000). Use of anastrozole has been found to reduce plasma concentrations of E2 by $86 \%$ in women (Geisler et al. 2001) and serum concentrations of $\mathrm{E} 2$ by $48 \%$ in men (Mauras et al. 2000). Administration of anastrozole may be useful in further defining the effects of decreased E2 on the IGF system in pigs without the confounding effects associated with castration. The objectives of this study were (i) to determine the dosage of anastrozole necessary to decrease serum concentrations of E2 in maturing boars, and (ii) to determine if administration of anastrozole to pre-pubertal growing boars decreases serum concentrations of $\mathrm{E} 2$ and affects components of the serum and AP IGF system vs untreated boars and barrows.

\section{Materials and Methods}

\section{Animals}

All experimental procedures were reviewed and approved by the South Dakota State University Institutional Animal Care and Use Committee.

Experiment 1 Twelve crossbred boars of similar age $(292.5 \pm 14.3$ days $)$ and weight $(158.8 \pm 4.4 \mathrm{~kg})$ were stratified by litter to one of three treatment groups $(n=4)$ on day 0 . Boars were penned separately and received free access to water. Treatment groups were 0,1 and $10 \mathrm{mg}$ anastrozole administered daily. Anastrozole was solubilized in absolute ethanol then applied to $235 \mathrm{~g}$ corn-soy-canola meal feed samples, and ethanol was allowed to evaporate overnight. The corn-soy-canola meal diet contained
3.4 Mcal metabolizable energy (ME) $/ \mathrm{kg}$ diet, $18 \%$ crude protein and $0.9 \%$ lysine. Each boar was fed the appropriate treatment at approximately $0900 \mathrm{~h}$. After consuming the amended feed, boars were fed the remaining portion of their ration. Boars were fed an amount of feed that contained 3-fold the energy requirements for maintenance each day. Blood samples $(10 \mathrm{ml})$ were collected from all pigs on days $0,8,15,29$ and 36 by jugular venipuncture.

Experiment 2 Twenty-four crossbred boars and 12 barrows of similar age (101.7 \pm 0.3 days) and weight $(44.7 \pm 1.0 \mathrm{~kg})$ were stratified by litter to one of three treatment groups $(n=12)$ on day 0 . Pigs were penned separately and received free access to water and fed a diet daily that contained $2 \cdot 5$-fold their energy requirements for maintenance. Treatment groups were anastrozoletreated boars $(n=12)$ administered $10 \mathrm{mg}$ anastrozole daily, untreated boars $(n=12)$ and barrows $(n=12)$. Anastrozole was solubilized in absolute ethanol and applied to $200 \mathrm{~g}$ corn-canola meal feed samples, then ethanol was allowed to evaporate overnight. The corn-canola meal diet contained $3 \cdot 1 \mathrm{Mcal} \mathrm{ME} / \mathrm{kg}, 17 \cdot 3 \%$ crude protein and $1 \cdot 1 \%$ lysine. Anastrozole-treated boars were fed the anastrozoleamended feed and untreated boars and barrows were fed their rations at approximately $0800 \mathrm{~h}$ each day. After consuming the anastrozole-amended feed, treated boars were fed the remaining portion of their ration. Blood samples $(10 \mathrm{ml})$ were collected from all pigs on days 0,15 , 29, 43, 58 and 71 by jugular venipuncture. Previous research has shown this sampling interval is adequate to accurately determine changes in circulating concentrations of steroids, IGF-I and IGFBPs (Clapper et al. 2000, Lee et al. 2002, Rempel \& Clapper 2002). Pigs were slaughtered on day 84, at which time blood samples and APs were collected.

Blood samples were allowed to clot overnight at $4{ }^{\circ} \mathrm{C}$, then serum was collected by centrifugation $(1500 \mathrm{~g}$ for $30 \mathrm{~min}$ at $4{ }^{\circ} \mathrm{C}$ ) and stored at $-20^{\circ} \mathrm{C}$. At slaughter, APs were trimmed of connective tissue, bisected midsaggitally, wrapped in foil, frozen in liquid nitrogen and stored at $-80{ }^{\circ} \mathrm{C}$.

\section{Measurement of E2}

Serum concentrations of E2 in were determined in duplicate by RIA (Kesler et al. 1977, Long \& Diekman 1984) in all samples taken from boars in Experiments 1 and 2. E2 (E-8875; Sigma Chemical Co., St Louis, MO, USA) was the standard, and $\left[{ }^{3} \mathrm{H}\right] \mathrm{E} 2$ (NET 517; NEN, Boston, MA, USA) was the tracer. Antisera (GDN \#244 antiestradiol-173-6-BSA) was used at a dilution of 1:20 000 . Sera $(500 \mu \mathrm{l})$ were extracted twice with $3 \mathrm{ml}$ diethyl ether. Recovery of $\left[{ }^{3} \mathrm{H}\right] \mathrm{E} 2$ added to porcine serum before extraction averaged $98 \pm 1 \cdot 5 \%$. Sensitivity of the assays was $4.8 \mathrm{pg} /$ tube for Experiment 1 and $4.0 \mathrm{pg} /$ tube for Experiment 2. Intra- and inter-assay coefficients of 
variation for Experiment 1 were $9 \cdot 0$ and 16.1\% respectively. Intra- and inter-assay coefficients of variation for Experiment 2 were $7 \cdot 2$ and $11 \cdot 0 \%$ respectively.

\section{Measurement of testosterone}

Serum concentrations of testosterone were determined in duplicate by RIA (Gay \& Kerlan 1978) in all samples taken from anastrozole-treated and untreated boars in Experiment 2. Testosterone (T-6147; Sigma) was the standard, and $\left[{ }^{3} \mathrm{H}\right]$ testosterone (TRK 402; Pharmacia Biotech, Piscataway, NJ, USA) was the tracer. Antisera (GDN \#250 anti-testosterone-11-BSA) was used at a dilution of 1:10 000. Sera $(50 \mu \mathrm{l})$ were extracted once with $3 \mathrm{ml}$ diethyl ether. Recovery of $\left[{ }^{3} \mathrm{H}\right]$ testosterone added to porcine serum before extraction averaged $99 \pm 1 \cdot 7 \%$. Sensitivity was $4 \cdot 2 \mathrm{pg} /$ tube. Intra- and inter-assay coefficients of variation for were 14.4 and $16.9 \%$ respectively.

\section{Measurement of IGF-I}

Serum and AP concentrations of IGF-I were determined in duplicate by RIA (Echternkamp et al. 1990, Funston et al. 1995) in all blood samples and APs collected in Experiment 2. One half of each AP was placed in a $15 \mathrm{ml}$ polypropylene tube (14-956-1J; Fisher Scientific, Pittsburgh, PA, USA) with $1 \mathrm{ml}$ homogenization buffer (1\% cholic acid, $0 \cdot 1 \%$ SDS, $200 \mu \mathrm{M}$ phenylmethylsulfonylfluoride, $100 \mu \mathrm{M}$ EDTA, $1 \mu \mathrm{M}$ leupeptin, $1 \mu \mathrm{M}$ pepstatin) and homogenized on ice with a T25 UltraTurrax tissue disperser (IKA Works, Wilmington, NC, USA) for $30 \mathrm{~s}$ at 20500 r.p.m. AP homogenates were diluted to $100 \mathrm{mg}$ AP tissue/ml homogenization buffer. Homogenates were centrifuged at $15000 \mathrm{~g}$ for $10 \mathrm{~min}$ at $4{ }^{\circ} \mathrm{C}$ and the supernatant removed and stored at $-20{ }^{\circ} \mathrm{C}$. Protein content of AP homogenates (1:10 dilution) was determined by the Bradford method using reagents supplied by Bio-Rad (Hercules, CA, USA). IGFBPs were extracted from serum and AP homogenates with a 1:17 ratio of sample to acidified ethanol $(12.5 \% 2 \mathrm{M}$ HCl:87.5\% absolute ethanol) (Daughaday et al. 1980). Extracted samples were centrifuged $\left(12000 \mathrm{~g}, 4^{\circ} \mathrm{C}\right)$ to separate the IGFBPs. A portion of the resulting supernatant was removed and neutralized with $0.855 \mathrm{M}$ Tris base, incubated an additional $4 \mathrm{~h}$ at $4{ }^{\circ} \mathrm{C}$, then centrifuged again at $12000 \mathrm{~g}$ at $4{ }^{\circ} \mathrm{C}$ to remove any additional IGFBPs. When samples of this extract, equivalent to the original serum or AP homogenate sample, were subjected to Western ligand blot analysis and subsequent phosphorimagery, no detected binding of ${ }^{125}$ I-IGF-I to IGFBPs was observed. Inhibition curves of the neutralized extracted serum ranging from 12.5 to $50 \mu \mathrm{l}$ were parallel to standard curves. Recombinant human IGF-I (GF-050; Austral Biological, San Ramon, CA, USA) was used as the standard and radioiodinated antigen. Antisera UB2-495 (National Hormone and Peptide Program,
National Institutes of Diabetes, Digestive and Kidney Diseases (NIDDK), Bethesda, MD, USA) was used at a dilution of 1:100 000. Recovery of ${ }^{125}$ I-IGF-I added to porcine serum before extraction averaged $89 \pm 5 \%$. Sensitivity was $14.8 \mathrm{pg} /$ tube. Intra- and inter-assay coefficients of variation were $7 \cdot 9$ and $8.1 \%$ respectively.

\section{Measurement of IGFBP}

Relative amounts of serum and AP IGFBP were analyzed by one-dimensional SDS-PAGE (Laemmli 1970) and Western ligand blot analysis (Hossenlopp et al. 1986, Howard \& Ford 1992) in all samples taken in Experiment 2. Sera $(3 \mu \mathrm{l})$ were electrophoresed through a $5 \%$ stacking gel and 10\% resolving gel. Aliquots of AP homogenate $(10 \mu \mathrm{g})$ were electrophoresed through a 5\% stacking gel and $12 \%$ resolving gel. Proteins were electrophoretically transferred to nitrocellulose membranes (Protran, $0 \cdot 22 \mu \mathrm{m}, \mathrm{BA}$ 83; Schleicher \& Schuell, Keene, NH, USA), and IGFBP activity was detected by incubating membranes with ${ }^{125}$ I-IGF-I $(500000$ c.p.m./ml Tris-buffered saline, 1\% BSA (A7030; Sigma), 0.1\% Tween-20). All treatments and bleeding dates were represented on each gel. Relative abundance of each IGFBP was determined by phosphorimagery (Bio-Rad). A control sample was electrophoresed on each gel, and relative abundance of each sample IGFBP was normalized to the relative abundance of the corresponding IGFBP in the control sample.

The identity of IGFBP- 2 and -5 in AP was confirmed by immunoprecipitation of proteins with specific antibodies (06-107 and 06-110 respectively; Upstate Biotechnologies, Inc., Lake Placid, NY, USA). The resulting supernatants, precipitates and non-immunoprecipitated AP samples were subjected to Western ligand blot analysis (Hossenlopp et al. 1986, Howard \& Ford 1992).

\section{Measurement of AP luteinizing hormone (LH)}

Anterior pituitary concentrations of $\mathrm{LH}$ were determined in triplicate by RIA in all APs collected in Experiment 2 (Clapper et al. 1998). Porcine LH (AFP11043B; National Hormone and Peptide Program, NIDDK) was used as the radioiodinated antigen and standard. LH antiserum (AFP15103194; National Hormone and Peptide Program, NIDDK) was used at a dilution of 1:300 000. AP homogenates were diluted $1: 25000$ in $0 \cdot 01 \mathrm{M}$ PBS $-0 \cdot 1 \%$ gelatin prior to assay. Intra-assay coefficient of variation was $4 \cdot 6 \%$. Sensitivity was $0 \cdot 1 \mathrm{ng} /$ tube.

\section{Measurement of AP growth hormone (GH)}

Anterior pituitary concentrations of GH were determined in triplicate by RIA in all APs collected in Experiment 2 (Klindt et al. 1983). Porcine GH (AFP10864B; National Hormone and Peptide Program, NIDDK) was used as the 
radioiodinated antigen and standard. $\mathrm{GH}$ anti-serum (AFP422801; National Hormone and Peptide Program, NIDDK) was used at a dilution of 1:60 000. AP homogenates were diluted $1: 100000$ in $0 \cdot 01 \mathrm{M}$ PBS- $0 \cdot 1 \%$ gelatin prior to assay. Intra-assay coefficient of variation was $3 \cdot 4 \%$. Sensitivity was $0 \cdot 1 \mathrm{ng} /$ tube.

\section{Statistical analysis}

Experiment 1 To determine differences among dosages of anastrozole, statistical analyses were performed using the general linearized model of the Statistical Analysis System (1999) (SAS). The model for determining differences in serum concentrations of E2 included $\mathrm{Y}_{\mathrm{ijkl}}=\mu+$ $\mathrm{Pig}_{\mathrm{i}}+$ Treatment $_{\mathrm{j}}+\mathrm{Pig}_{\mathrm{i}}\left(\right.$ Treatment $_{\mathrm{j}}+$ Date $_{\mathrm{k}}+$ Treatment $_{\mathrm{j}} \times$ Date $_{\mathrm{k}}+\operatorname{Pig}_{\mathrm{i}}(\text { Treatment })_{\mathrm{j}} \times$ Date $_{\mathrm{k}}$. Pig within treatment was the whole plot error term used to test the effect of treatment. Pig within treatment by date was the subplot error term used to test pig, date and treatment by date effects.

Experiment 2 To determine differences among treatments, statistical analyses were performed using the general linearized model of SAS. Because mean serum concentrations of IGF-I differed among groups on day 0 , differences in mean serum concentrations of IGF-I were determined by analyzing the remaining data as a percentage of day 0 (basal) values for each treatment group. The model for determining differences in serum concentrations of E2, testosterone, percentage of basal IGF-I and relative amounts of serum IGFBP was $\mathrm{Y}_{\mathrm{ijkl}}=\mu+\mathrm{Pig}_{\mathrm{i}}+$ Treatment $_{\mathrm{j}}+$ $\operatorname{Pig}_{i}\left(\right.$ Treatment $_{j}+$ Date $_{\mathrm{k}}+$ Treatment $_{\mathrm{j}} \times$ Date $_{\mathrm{k}}+$ Pig $_{\mathrm{i}}($ Treatment $)_{j} \times$ Date $_{k}$. Pig within treatment was the whole plot error term used to test the effect of treatment. Pig within treatment by date was the subplot error term used to test pig, date and treatment by date effects. The effect of anastrozole on AP concentrations of LH, GH, IGF-I and relative amounts of AP IGFBP was analyzed by one-way ANOVA of SAS.

\section{Results}

\section{Experiment 1}

Mean serum concentrations of E2 did not differ $(P>0 \cdot 05)$ among groups of boars from day 0 through to 8 (Fig. 1). From day 15 through to 29 , mean serum concentrations of E2 were greater $(P<0 \cdot 01)$ in boars administered $0 \mathrm{mg} /$ day anastrozole vs those administered 1 and $10 \mathrm{mg} /$ day. By day 36, mean serum concentrations of E2 were less in the boars administered $10 \mathrm{mg} /$ day anastrozole vs those administered 0 and $1 \mathrm{mg} /$ day. Mean serum concentrations of E2 did not differ $(P>0 \cdot 05)$ on days 0 and 8 in boars administered $0 \mathrm{mg}$ /day anastrozole; however, mean serum concentrations of E2 were increased $(P<0 \cdot 05)$ on day 15

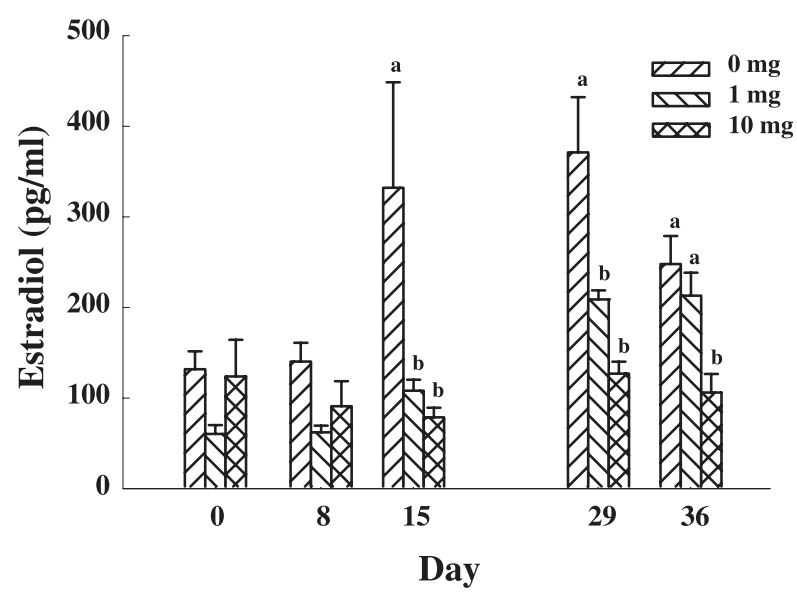

Figure 1 Mean serum concentrations of E2 in boars administered $0(n=4), 1(n=4)$ or $10 \mathrm{mg}(n=4)$ anastrozole from day 0 through to 36 in Experiment 1. Means are least-square means \pm S.E.M.

${ }^{\mathrm{ab}}$ Means with different letters differ $(P<0 \cdot 05)$ by treatment within a day.

through to 36 compared with previous days. Mean serum concentrations of E2 did not differ $(P>0 \cdot 05)$ on day 0 through to 15 in boars administered $1 \mathrm{mg} /$ day anastrozole; however, mean serum concentrations of $\mathrm{E} 2$ were increased $(P<0 \cdot 05)$ on day 29 through to 36 compared with previous days. Mean serum concentrations of E2 did not differ $(P>0 \cdot 05)$ from day 0 through to 36 in boars administered $10 \mathrm{mg} /$ day anastrozole.

\section{Experiment 2}

Mean serum concentrations of E2 did not differ $(P>0 \cdot 05)$ between untreated boars and anastrozole-treated boars on day 0 (Fig. 2). On day 15 through to 84, mean serum concentrations of E2 were greater $(P<0 \cdot 05)$ in the untreated boars vs the anastrozole-treated boars. Mean serum concentrations of E2 did not differ $(P>0.05)$ in untreated boars from day 0 to 29 but increased on day 43 through to 71 (Fig. 2) and were greater $(P<0.05)$ on day 84 than all other days. In anastrozole-treated boars, mean serum concentrations of E2 decreased $(P<0 \cdot 05)$ on day 15 compared with day 0 and remained decreased $(P<0 \cdot 05)$ through to day 71. Mean serum concentrations of E2 were greater $(P<0 \cdot 05)$ on day 84 vs day 0 in anastrozoletreated boars.

Mean serum concentrations of testosterone did not differ $(P>0.05)$ between untreated boars and anastrozoletreated boars on day 0 through to 71 (Fig. 3). On day 84, mean serum concentrations of testosterone were greater $(P<0 \cdot 01)$ in the untreated boars vs the anastrozole-treated boars. Mean serum concentrations of testosterone were greater $(P<0 \cdot 01)$ in untreated boars and anastrozoletreated boars on day 84 than on any other day.

Because mean serum concentrations of IGF-I differed $(P<0 \cdot 05)$ among groups on day 0 (untreated boars, 


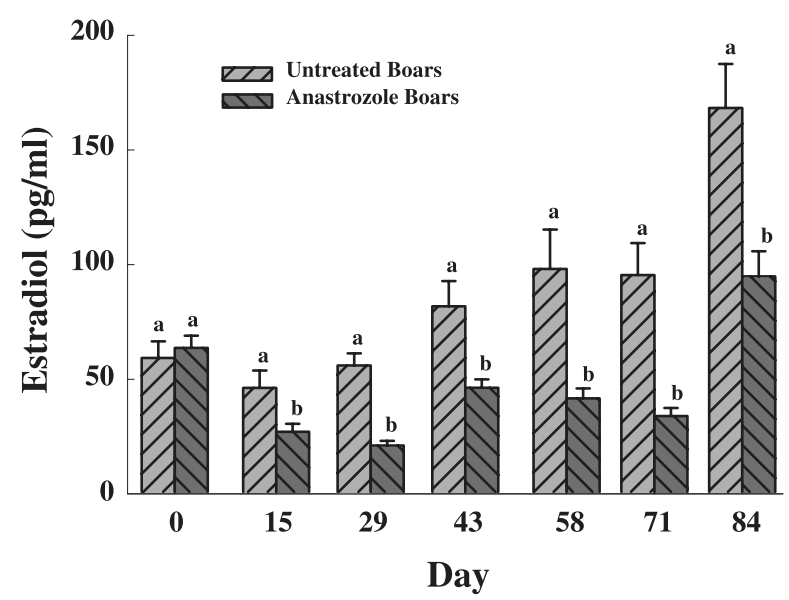

Figure 2 Mean serum concentrations of E2 in untreated boars $(n=12)$ and anastrozole-treated boars $(n=12)$ from day 0 through to 84 in Experiment 2. Means are least-square means \pm S.E.M.

${ }^{\mathrm{ab}}$ Means with different letters differ $(P<0.05)$ by treatment within a day.

$104 \cdot 1 \pm 10 \cdot 7$; anastrozole-treated boars, $128 \cdot 3 \pm 11 \cdot 7$; barrows, $82 \cdot 3 \pm 10.5 \mathrm{ng} / \mathrm{ml}$ ) differences in mean serum concentrations of IGF-I were determined by analyzing the remaining data as a percentage of day 0 values (basal) for each treatment group (Fig. 4). Mean percentage of basal IGF-I was not different $(P>0.05)$ among anastrozoletreated boars, untreated boars and barrows from day 0 through to 29. Mean percentage of basal IGF-I was greater in untreated boars than anastrozole-treated boars and barrows from day 58 through to 84 . Mean percentage of basal IGF-I increased $(P<0.05)$ in anastrozole-treated boars and barrows from day 0 through to 43 ; however, mean percentage of basal IGF-I was not different from day

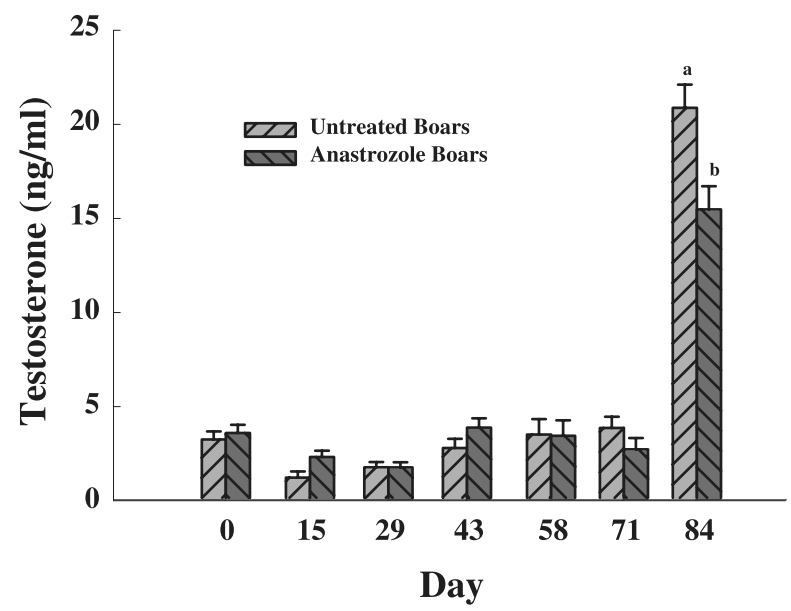

Figure 3 Mean serum concentrations of testosterone in untreated boars $(n=12)$ and anastrozole-treated boars $(n=12)$ from day 0 to 84 in Experiment 2. Means are least-square means \pm S.E.M. ${ }^{\text {ab Means }}$ with different letters differ $(P<0 \cdot 01)$ according to day and (or) treatment.

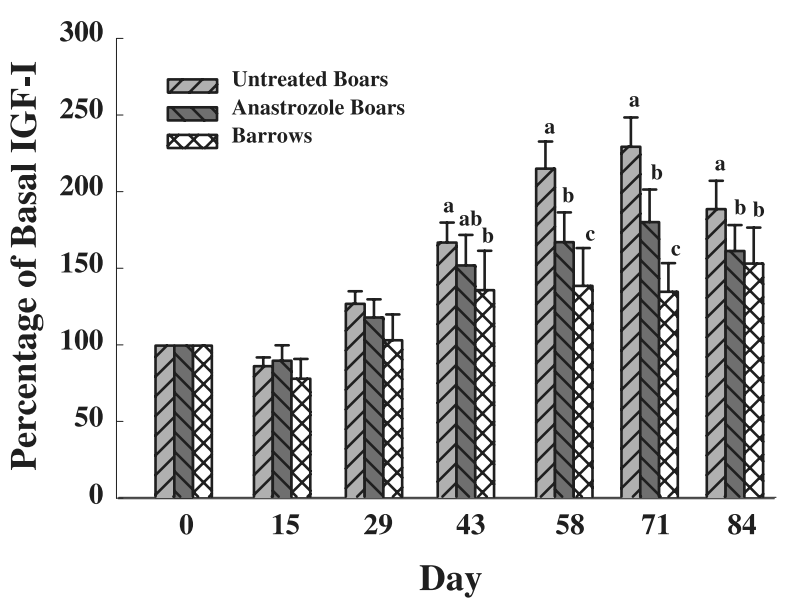

Figure 4 Mean percentage of basal IGF-I in untreated boars $(n=12)$, anastrozole boars $(n=12)$ and barrows $(n=12)$ from day 0 through to 84 of experiment 2 . Means are least-square means \pm S.E.M. of percentage of day 0 values for each treatment group. ${ }^{\text {abc } M e a n s}$ with different letters differ $(P<0 \cdot 05)$ by treatment within a day.

58 through to 84 within anastrozole-treated boars and barrows. Mean percentage of basal IGF-I increased $(P<0 \cdot 05)$ from day 29 through to 84 in untreated boars.

Relative amounts of serum IGFBP were determined by Western ligand blot analysis. Based upon the similarity of molecular masses and results of immunoprecipitation of IGFBP in porcine serum performed by Klindt et al. (1998), these serum IGFBPs were identified as 46 and $41 \mathrm{kDa}$ forms of IGFBP-3, $34 \mathrm{kDa}$ IGFBP-2, and 28 and $24 \mathrm{kDa}$ forms of IGFBP-4. No treatment by day interaction was detected $(P>0.05)$ for relative amounts of any serum IGFBP. Mean relative amounts of the 46 and $41 \mathrm{kDa}$ forms of IGFBP-3 in serum did not differ $(P>0.05)$ between untreated boars and anastrozole-treated boars, but mean relative amounts of each form of IGFBP-3 were greater $(P<0 \cdot 01)$ in untreated and anastrozole-treated boars vs barrows (Table 1). Mean relative amounts of the $24 \mathrm{kDa}$ form of IGFBP-4 in serum were greater $(P<0 \cdot 01)$ in anastrozole-treated boars compared with untreated boars and barrows; however, mean relative amounts in untreated boars and barrows did not differ $(P>0 \cdot 05)$. No treatment effect was detected $(P>0.05)$ in mean relative amounts of any other serum IGFBP among treatment groups.

Western ligand blot analysis identified two IGFBPs in the AP, determined as $33 \mathrm{kDa}$ IGFBP-2 and $29 \mathrm{kDa}$ IGFBP-5. Identity was based upon the similarity of results found by Rempel \& Clapper (2002) after immunoprecipitation of IGFBP with specific antibodies. Mean relative amounts of AP IGFBP-2 and -5 were decreased $(P<0 \cdot 01)$ in anastrozole-treated boars compared with untreated boars, but mean relative amounts of AP IGFBP-2 and -5 were greater $(P<0 \cdot 01)$ in each group of boars vs barrows (Fig. 5). 
Table 1 Mean relative amounts of serum IGFBPs in untreated boars $(n=12)$, anastrozole-treated boars $(n=12)$ and barrows $(n=12)$ in experiment $2^{\text {a }}$

\begin{tabular}{|c|c|c|c|c|}
\hline & Untreated boars & Anastrozole boars & Barrows & $P$ \\
\hline \multicolumn{5}{|l|}{ IGFBP } \\
\hline IGFBP-3 (46 kDa) & $1 \cdot 42 \pm 0 \cdot 06^{b}$ & $1 \cdot 49 \pm 0.05^{b}$ & $1 \cdot 16 \pm 0.05^{c}$ & 0.01 \\
\hline IGFBP-3 (41 kDa) & $1 \cdot 63 \pm 0.08^{b}$ & $1 \cdot 69 \pm 0.06^{b}$ & $1 \cdot 23 \pm 0 \cdot 04^{\mathrm{c}}$ & $0 \cdot 01$ \\
\hline IGFBP-2 & $1 \cdot 25 \pm 0 \cdot 04$ & $1 \cdot 18 \pm 0 \cdot 03$ & $1 \cdot 29 \pm 0 \cdot 03$ & $0 \cdot 20$ \\
\hline IGFBP-4 (28 kDa) & $1 \cdot 08 \pm 0.03$ & $1 \cdot 11 \pm 0 \cdot 03$ & $1 \cdot 05 \pm 0.02$ & $0 \cdot 12$ \\
\hline IGFBP-4 (24 kDa) & $1 \cdot 03 \pm 0.02^{c}$ & $1 \cdot 10 \pm 0 \cdot 02^{b}$ & $1 \cdot 04 \pm 0.02^{\mathrm{C}}$ & $0 \cdot 01$ \\
\hline
\end{tabular}

${ }^{\mathrm{a}}$ Means are expressed as least-square means \pm S.E.M. Data are expressed in arbitrary densitometric units.

$\mathrm{b}, \mathrm{c}$ Means within a row with different letters differ $(P<0 \cdot 01)$ by treatment.

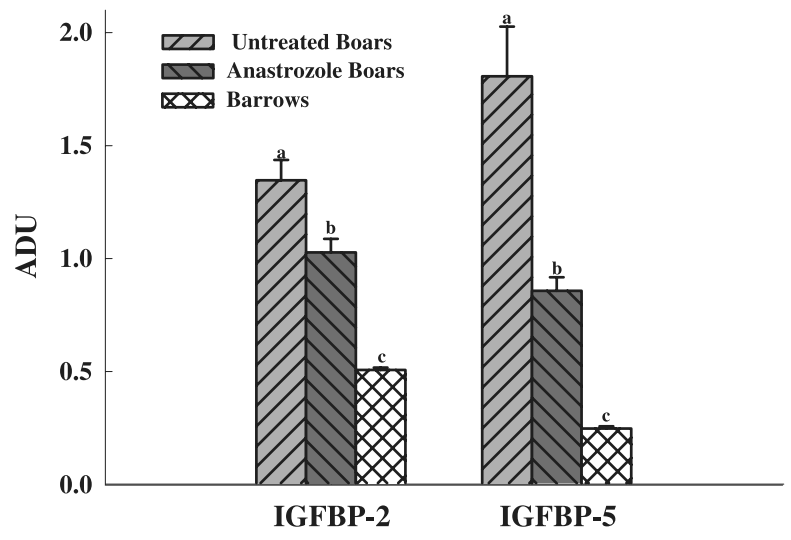

Figure 5 Mean relative amounts of AP IGFBP-2 and -5 in untreated boars $(n=12)$, anastrozole-treated boars $(n=12)$ and barrows $(n=12)$. Means are least-square means \pm s.E.M. Data are

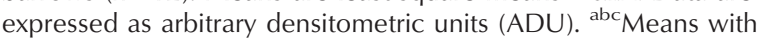
different letters differ $(P<0 \cdot 01)$ by treatment.

Mean AP concentrations of LH, GH and IGF-I did not differ $(P>0.05)$ between untreated boars and anastrozoletreated boars; however, mean AP concentrations of $\mathrm{LH}$, GH and IGF-I were each greater $(P<0 \cdot 01)$ in untreated and anastrozole-treated boars vs barrows (Table 2).

\section{Discussion}

Administration of E2 has been found to affect serum concentrations of IGF-I and relative amounts of IGFBP (Rempel \& Clapper 2002). However, other gonadal hormones/factors may also play a role in regulation of the
IGF-I system. By leaving the animal gonadally intact and simultaneously decreasing serum concentrations of E2, it may be possible to further study the influence of E2 on the peripheral and AP IGF system. Anastrozole is a third generation, non-steroidal, competitive aromatase inhibitor that is effective in reducing E2 synthesis by preventing the conversion of androgens to estrogens (Brodie \& Long 2001, Dowsett et al. 2001).

Administration of $1 \mathrm{mg}$ /day anastrozole is the recommended dosage for aromatase inhibition and suppression of E2 in postmenopausal breast cancer patients (Plourde et al. 1994, Geisler et al. 1996, Jonat et al. 1996, Yates et al. 1996). Administration of $10 \mathrm{mg} /$ day anastrozole was effective in preventing the increase in serum concentrations of E2 in maturing boars and decreased serum concentrations of $\mathrm{E} 2$ in prepubertal boars. The dosage necessary to decrease E2 synthesis in the pig may differ from that in humans due to activity or amount of the aromatase enzyme present in each species, because testicular estradiol synthesis as well as aromatase activity can vary among species (Kelch et al. 1972, Nitta et al. 1993, Inkster et al. 1995).

Use of anastrozole has been associated with increased circulating concentrations of testosterone in men (Mauras et al. 2000, Taxel et al. 2001), male monkeys and dogs (Plourde et al. 1994). An increase in serum concentrations of testosterone would be expected because administration of anastrozole prevents/reduces the synthesis of E2 from testosterone (Kellis \& Vickery 1987). Serum concentrations of testosterone did not differ between untreated boars and anastrozole-treated boars throughout the majority of the experiment but increased in both groups

Table 2 Mean anterior pituitary gland concentrations of LH, GH and IGF-I in untreated boars $(n=12)$, anastrozole-treated boars $(n=12)$ and barrows $(n=12)$ in Experiment $2^{\text {a }}$

\begin{tabular}{|c|c|c|c|c|}
\hline & Untreated boars & Anastrozole boars & Barrows & $P$ value \\
\hline LH & $2870 \cdot 5 \pm 344 \cdot 4^{b}$ & $2958 \cdot 6 \pm 363 \cdot 4^{b}$ & $1509 \cdot 8 \pm 163 \cdot 6^{c}$ & $0 \cdot 01$ \\
\hline $\mathrm{GH}$ & $7365 \cdot 4 \pm 386 \cdot 2^{b}$ & $7200 \cdot 3 \pm 522 \cdot 2^{b}$ & $5653 \cdot 4 \pm 335 \cdot 8^{c}$ & $0 \cdot 01$ \\
\hline IGF-I & $200 \cdot 9 \pm 5 \cdot 9^{b}$ & $188 \cdot 0 \pm 10 \cdot 9^{b}$ & $75 \cdot 3 \pm 7 \cdot 8^{\mathrm{c}}$ & $0 \cdot 01$ \\
\hline
\end{tabular}

Means are expressed as least-square means \pm S.E.M. Means are in $\mathrm{ng} / \mathrm{mg}$.

${ }_{b, c}$ Means within a row with different letters differ $(P<0 \cdot 01)$ by treatment. 
of boars near the end of the experiment. Similar to results found by Clapper et al. (2000), Rempel \& Clapper (2002) and Allrich et al. (1982), mean serum concentrations of testosterone increased in both groups of boars at an age when they would be expected to reach puberty and the magnitude of the increase was indicative of that observed at puberty. Circulating concentrations of E2 are much greater in boars than in postmenopausal women (Geisler et al. 1996, 2002) and men (Mauras et al. 2000). Therefore, sufficient E2 may still have been synthesized in the boars to obviate the increase in serum concentrations of testosterone. The amount of E2 synthesized by the testis is variable among species (Kelch et al. 1972), and aromatase enzyme activity has also been reported to vary among species (Nitta et al. 1993, Inkster et al. 1995). Similar results have been reported in older men where administration of anastrozole decreased serum concentrations of estradiol but failed to increase serum concentrations of testosterone (Veldhuis \& Iranmanesh 2005). These authors proposed that these results could be due to a change in the pattern of LH release, decreased LH bioactivity or diminished LH uptake by the testis. Whether this occurs in the boar awaits further investigation.

Rempel \& Clapper (2002) previously reported that administration of E2 implants to barrows increased serum concentrations of IGF-I. Therefore, when serum concentrations of E2 decreased, a concomitant decrease in serum concentrations of IGF-I would be expected. In the present study, serum concentrations of E2 and the percentage increase in IGF-I were less in the anastrozole-treated boars compared with untreated boars. Testosterone has been found to increase circulating concentrations of IGF-I in hypogonadal men (Weissberger \& Ho 1993) and castrate baboons (Crawford \& Handelsman 1996). However, it appears E2 may be a more potent modulator of circulating levels of IGF-I in the boar, because the percentage increase in circulating IGF-I was less in anastrozole-treated boars compared with untreated boars despite both groups having similar circulating concentrations of testosterone. Similar to the findings of Clapper et al. (2000), Dunshea et al. (1993) and Owens et al. (1999), the percentage increase in serum concentrations of IGF-I was greater in each group of boars than in barrows from day 43 through to 84 of the study. The fact that serum concentrations of IGF-I were still greater in anastrozole-treated boars compared with barrows may have been due to the inability of the anastrozole to completely block estradiol synthesis.

Previous research has demonstrated that administration of E2 implants to barrows increased serum concentrations of IGF-I and relative amounts of the $41 \mathrm{kDa}$ IGFBP-3 (Rempel \& Clapper 2002). Relative amounts of both forms of IGFBP-3 in serum were greater in untreated boars and anastrozole-treated boars vs barrows. Similarly, Clapper et al. (2000) found relative amounts of both forms of serum IGFBP-3, as well as serum concentrations of E2 and IGF-I, were greater in boars than in barrows.
Administration of E2 implants to ovariectomized ewes increased serum concentrations of IGF-I and relative amounts of the $44 \mathrm{kDa}$ form of serum IGFBP-3 (Clapper et al. 1998). The lack of a difference in relative amounts of serum IGFBP-3 in untreated and anastrozole-treated boars may be explained by the fact that serum concentrations of E2 may not have been decreased enough in anastrozole-treated boars to affect relative amounts of IGFBP-3. Whether a threshold level of E2 exists to affect serum IGFBP-3 in the pig has not been determined. A similar phenomenon has been reported in postmenopausal women where increasing amounts of $\mathrm{E} 2$ have no effect on circulating levels of IGF-I but not IGFBP-3 (Garnero et al. 1999).

Clapper et al. (2000) found relative amounts of the 24 kDa IGFBP-4 in serum did not differ between boars and barrows. In addition, administration of $\mathrm{E} 2$ implants to barrows did not affect relative amounts of the $24 \mathrm{kDa}$ IGFBP-4 in serum compared with untreated barrows, and relative amounts of the $24 \mathrm{kDa}$ IGFBP-4 in the serum did not differ among E2-implanted barrows, boars and unimplanted barrows (Rempel \& Clapper 2002). In the present study, relative amounts of the $24 \mathrm{kDa}$ IGFBP-4 in serum were greater in anastrozole-treated boars than in other treatment groups. These apparent disparate results may have been due to changes in aromatase activity or expression. Mazerbourg et al. (2001) reported that expression of an intrafollicular IGFBP-4-degrading protease in porcine ovaries was positively correlated with expression of aromatase. When anastrozole decreased circulating levels of estradiol, a compensatory increase in aromatase activity and/or expression would be expected due to loss of negative feedback. Perhaps this increase in aromatase was accompanied by an increase in IGFBP-4 protease activity. Increased relative amounts of the $24 \mathrm{kDa}$ form of IGFBP-4 in anastrozole-treated boars could function to increase the bioavailability of IGF-I because the $24 \mathrm{kDa}$ form of IGFBP-4 has less affinity for IGF-I than the $28 \mathrm{kDa}$ form of IGFBP-4 (Jones \& Clemmons 1995). However, exact mechanisms by which this occurred were not within the scope of this study and remain to be determined.

In the present study, decreased serum concentrations of E2 did not affect AP concentrations of LH in anastrozoletreated boars compared with untreated boars. Similarly, administration of E2 implants to barrows did not affect AP concentrations of LH compared with boars and unimplanted barrows (Rempel \& Clapper 2002). However, untreated and anastrozole-treated boars had greater mean AP concentrations of LH compared with barrows. Serum concentrations of E2 in both groups of boars may have increased inhibitory control over LH release from the AP, which would allow AP concentrations of $\mathrm{LH}$ to be maintained by decreasing its release (Lindzey et al. 1998, Hayes et al. 2000).

AP concentrations of GH did not differ between untreated boars and anastrozole-treated boars. In a similar 
fashion, administration of E2 implants to barrows did not affect AP concentrations of GH compared with boars and unimplanted barrows (Rempel \& Clapper 2002). However, in the present study, AP concentrations of GH were greater in both groups of boars in comparison with barrows. E2 has been found to promote $\mathrm{GH}$ secretion in baboons (Copeland et al. 1984) and increase GH synthesis, content and release from cultured rat AP cells (Simard et al. 1986). In wethers, administration of zeranol, an estrogenic compound, increased GH pulse amplitude and serum concentrations of GH (Hufstedler et al. 1996). Serum concentrations of E2 may have been elevated enough in anastrozole-treated boars to maintain mean AP concentrations of GH and IGF-I.

It was previously shown that administration of E2 increased expression of IGF-I in the AP in gonadectomized rats (Michels et al. 1993) and in the uterus in ovariectomized hypophysectomized rats (Murphy \& Friesen 1988) and ovariectomized rats (Murphy et al. 1987). Additionally, administration of $E 2$ increased uterine content of IGF-I in ovariectomized rats (Murphy et al. 1987), prepubertal gilts and ovariectomized gilts (Simmen et al. 1990). Previous research demonstrated that administration of E2 to barrows increased AP concentrations of IGF-I (Rempel \& Clapper 2002). The fact that AP concentrations of IGF-I were similar between anastrozoletreated and untreated boars in the present experiment may be due to the fact that although serum concentrations of E2 were decreased in the anastrozole-treated boars, they may not have been reduced enough to affect AP concentrations of IGF-I.

Relative amounts of AP IGFBP-2 and -5 decreased in anastrozole-treated boars compared with untreated boars. Conversely, Rempel \& Clapper (2002) found that acute administration of E2 implants to barrows increased relative amounts of IGFBP-2 and -5 in the AP vs unimplanted barrows, although not to the levels observed in untreated boars. E2 has been found to affect the expression and amount of IGFBP-2 and -5 in other species as well. Clapper et al. (1998) reported administration of E2 implants to ovariectomized ewes increased expression of IGFBP-2 and tended to increase relative amounts of IGFBP-2 in the AP. Administration of E2 has also been found to increase expression of IGFBP-2 in the AP in rats (Michels et al. 1993). In ovariectomized monkeys, administration of E2 increased synthesis of IGFBP-2 and -5 in the uterine myometrium (Adesanya et al. 1996). During the estrous cycle in ewes, expression of IGFBP-5 in the uterine luminal epithelium and inner myometrium has been found to increase around ovulation and decrease during the late luteal phase (Gadd et al. 2000), times coincident with increased and decreased circulating concentrations of estradiol respectively. Administration of E2 to equine granulosa cells also increased relative amounts of IGFBP-2 (Davidson et al. 2002). Thus, E2 appears to be a regulator of relative amounts and expression of IGFBP-2 and -5 . IGFBP-2 and -5 in the AP may function to bind IGF-I and enhance IGF-I activity (Michels et al. 1993, Adesanya et al. 1996). In addition to modulating IGF-I activity, IGFBP-2 and -5 have been found to have growth-promoting effects independently of IGF-I. IGFBP-2 stimulated cell proliferation in rat osteoblast cells in vitro (Slootweg et al. 1995). Furthermore, overexpression of IGFBP-2 in mouse adrenocortical tumor cells increased cell proliferation in culture (Hoeflich et al. 2000). Co-incubation of IGFBP-5 with mouse osteoblast cells increased cell proliferation (Mohan \& Baylink 1995), while incubation of IGFBP-5 with human osteoblast cells increased cell differentiation (Richman et al. 1999). The current experiment demonstrated that the porcine AP IGF system is sensitive to changes in circulating concentrations of estradiol. However, other gonadal hormones and/or factors may also regulate AP IGFBP because Rempel \& Clapper (2002) found boars had greater relative amounts of AP IGFBP-2 and -5 vs E2-implanted and unimplanted barrows.

In the present study, administration of $10 \mathrm{mg} /$ day anastrozole to growing boars decreased mean serum concentrations of E2 and mean relative amounts of AP IGFBP-2 and -5 compared with untreated boars. These data support the role of E2 in regulating components of the AP IGF system in pigs. Although E2 has been found to regulate other components of the circulating and AP IGF-I system, a greater magnitude in E2 reduction may be necessary to affect the peripheral IGF-I system. The possible influences of other gonadal hormones/factors, either alone or in conjunction with E2, to regulate components of the IGF-I system cannot be discounted.

\section{Acknowledgements}

The authors wish to thank Dr A F Parlow and the National Institutes of Diabetes, Digestive and Kidney Diseases, National Hormone and Pituitary Program for the reagents for GH, LH and IGF-I. The authors are indebted to Dr Neill Carman, AstraZeneca, for the donation of anastrozole. This work was presented in part at the Society for the Study of Reproduction 2003 Meeting, Cincinnati, $\mathrm{OH}$, and the Midwestern Section of the American Society of Animal Science 2004 Meeting, Des Moines, IA. This is Journal Paper No. 3481 of the South Dakota State University Agricultural Experiment Station, Brookings, SD. The authors declare that there is no conflict of interest that would prejudice the impartiality of this scientific work.

\section{References}

Adesanya OO, Zhou J \& Bondy CA 1996 Sex steroid regulation of insulin-like growth factor system gene expression and proliferation in primate myometrium. Journal of Clinical Endocrinology and Metabolism 81 1967-1974. 
Allrich RD, Christenson RK, Ford JJ \& Zimmerman DR 1982 Pubertal development of the boar: testosterone, estradiol-17 beta, cortisol and $\mathrm{LH}$ concentrations before and after castration at various ages. Journal of Animal Science 55 1139-1146.

Brodie A \& Long B 2001 Aromatase inhibition and inactivation. Clinical Cancer Research 7 4343s-4349s; discussion 4411s-4412s.

Clapper JA, Snyder JL, Roberts AJ, Hamernik DL \& Moss GE 1998 Estradiol increases relative amounts of insulin-like growth factor binding protein (IGFBP)-3 in serum and expression of IGFBP-2 in anterior pituitaries of ewes. Biology of Reproduction 59 124-130.

Clapper JA, Clark TM \& Rempel LA 2000 Serum concentrations of IGF-I, estradiol-17 beta, testosterone, and relative amounts of IGF binding proteins (IGFBP) in growing boars, barrows, and gilts. Journal of Animal Science $\mathbf{7 8}$ 2581-2588.

Copeland KC, Johnson DM, Kuehl TJ \& Castracane VD 1984 Estrogen stimulates growth hormone and somatomedin-C in castrate and intact female baboons. Journal of Clinical Endocrinology and Metabolism 58 698-703.

Crawford BA \& Handelsman DJ 1996 Androgens regulate circulating levels of insulin-like growth factor (IGF)-I and IGF binding protein-3 during puberty in male baboons. Journal of Clinical Endocrinology and Metabolism 81 65-72.

Daughaday WH, Mariz IK \& Blethen SL 1980 Inhibition of access of bound somatomedin to membrane receptor and immunobinding sites: a comparison of radioreceptor and radioimmunoassay of somatomedin in native and acid-ethanol-extracted serum. Journal of Clinical Endocrinology and Metabolism 51 781-788.

Davidson TR, Chamberlain CS, Bridges TS \& Spicer LJ 2002 Effect of follicle size on in vitro production of steroids and insulin-like growth factor (IGF)-I, IGF-II, and the IGF-binding proteins by equine ovarian granulosa cells. Biology of Reproduction $\mathbf{6 6}$ $1640-1648$

De Wilde RO \& Lauwers H 1984 The effect of parenteral use of estradiol, progesterone, testosterone and trenbolone on growth and carcass composition in pigs. Journal of Animal Science 59 1501-1509.

Dowsett M, Cuzick J, Howell A \& Jackson I 2001 Pharmacokinetics of anastrozole and tamoxifen alone, and in combination, during adjuvant endocrine therapy for early breast cancer in postmenopausal women: a sub-protocol of the 'Arimidex and Tamoxifen Alone or in Combination' (ATAC) trial. British Journal of Cancer 85 317-324.

Dunshea FR, King RH, Campbell RG, Sainz RD \& Kim YS 1993 Interrelationships between sex and ractopamine on protein and lipid deposition in rapidly growing pigs. Journal of Animal Science $\mathbf{7 1}$ 2919-2930

Echternkamp SE, Spicer LJ, Gregory KE, Canning SF \& Hammond JM 1990 Concentrations of insulin-like growth factor-I in blood and ovarian follicular fluid of cattle selected for twins. Biology of Reproduction 43 8-14.

Enright WJ, Quirke JF, Gluckman PD, Breier BH, Kennedy LG, Hart LC, Roche JF, Coert A \& Allen P 1990 Effects of long-term administration of pituitary-derived bovine growth hormone and estradiol on growth in steers. Journal of Animal Science $\mathbf{6 8}$ 2345-2356.

Funston RN, Moss GE \& Roberts AJ 1995 Insulin-like growth factor-I (IGF-I) and IGF-binding proteins in bovine sera and pituitaries at different stages of the estrous cycle. Endocrinology 136 62-68.

Gadd TS, Osgerby JC \& Wathes DC 2000 Regulation and localization of insulin-like growth factor binding protein-5 gene expression in the uterus and placenta of the cyclic and early pregnant ewe. Biology of Reproduction 62 1415-1421.

Garnero P, Tsouderos Y, Marton I, Pelissier C, Varin C \& Delmas PD 1999 Effects of intranasal 17 beta-estradiol on bone turnover and serum insulin-like growth factor I in postmenopausal women. Journal of Clinical Endocrinology and Metabolism 84 2390-2397.
Gay VL \& Kerlan JT 1978 Serum LH and FSH following passive immunization against circulating testosterone in the intact male rat and in orchidectomized rats bearing subcutaneous silastic implants of testosterone. Archives of Andrology 1 257-266.

Geisler J, King N, Dowsett M, Ottestad L, Lundgren S, Walton P, Kormeset PO \& Lonning PE 1996 Influence of anastrozole (Arimidex), a selective, non-steroidal aromatase inhibitor, on in vivo aromatisation and plasma oestrogen levels in postmenopausal women with breast cancer. British Journal of Cancer 74 1286-1291.

Geisler J, Detre S, Berntsen H, Ottestad L, Lindtjorn B, Dowsett M \& Einstein Lonning P 2001 Influence of neoadjuvant anastrozole (Arimidex) on intratumoral estrogen levels and proliferation markers in patients with locally advanced breast cancer. Clinical Cancer Research 7 1230-1236.

Geisler J, Haynes B, Anker G, Dowsett M \& Lonning PE 2002 Influence of letrozole and anastrozole on total body aromatization and plasma estrogen levels in postmenopausal breast cancer patients evaluated in a randomized, cross-over study. Journal of Clinical Oncology 20 751-757.

Hayes FJ, Seminara SB, Decruz S, Boepple PA \& Crowley WF Jr 2000 Aromatase inhibition in the human male reveals a hypothalamic site of estrogen feedback. Journal of Clinical Endocrinology and Metabolism 85 3027-3035.

Hays CL, Davenport GM, Osborn TG \& Mulvaney DR 1995 Effect of dietary protein and estradiol-17 beta on growth and insulin-like growth factor I in cattle during realimentation. Journal of Animal Science 73 589-597.

Hoeflich A, Fettscher O, Lahm H, Blum WF, Kolb HJ, Engelhardt D, Wolf E \& Weber MM 2000 Overexpression of insulin-like growth factor-binding protein-2 results in increased tumorigenic potential in Y-1 adrenocortical tumor cells. Cancer Research 60 834-838.

Hossenlopp P, Seurin D, Segovia-Quinson B, Hardouin S \& Binoux M 1986 Analysis of serum insulin-like growth factor binding proteins using western blotting: use of the method for titration of the binding proteins and competitive binding studies. Analytical Biochemistry 154 138-143.

Howard HJ \& Ford JJ 1992 Relationships among concentrations of steroids, inhibin, insulin-like growth factor-I (IGF-I), and IGF-binding proteins during follicular development in weaned sows. Biology of Reproduction 47 193-201.

Hufstedler GD, Gillman PL, Carstens GE, Greene LW \& Turner ND 1996 Physiological and hormonal responses of lambs repeatedly implanted with zeranol and provided two levels of feed intake. Journal of Animal Science 74 2376-2384.

Inkster S, Yue W \& Brodie A 1995 Human testicular aromatase: immunocytochemical and biochemical studies. Journal of Clinical Endocrinology and Metabolism 80 1941-1947.

Jonat W, Howell A, Blomqvist C, Eiermann W, Winblad G, Tyrrell C, Mauriac L, Roche H, Lundgren S, Hellmund R \& Azab M 1996 A randomised trial comparing two doses of the new selective aromatase inhibitor anastrozole (Arimidex) with megestrol acetate in postmenopausal patients with advanced breast cancer. European Journal of Cancer 32A 404-412.

Jones JI \& Clemmons DR 1995 Insulin-like growth factors and their binding proteins: biological actions. Endocrine Reviews 16 3-34.

Kelch RP, Jenner MR, Weinstein R, Kaplan SL \& Grumbach MM 1972 Estradiol and testosterone secretion by human, simian, and canine testes, in males with hypogonadism and in male pseudohermaphrodites with the feminizing testes syndrome. Journal of Clinical Investigation $\mathbf{5 1} 824-830$.

Kellis JT Jr \& Vickery LE 1987 Purification and characterization of human placental aromatase cytochrome P-450. Journal of Biological Chemistry 262 4413-4420.

Kesler DJ, Garverick HA, Youngquist RS, Elmore RG \& Bierschwal CJ 1977 Effect of days postpartum and endogenous reproductive hormones on GnRH-induced LH release in dairy cows. Journal of Animal Science 45 797-803. 
Klindt J, Ford JJ, Berardinelli JG \& Anderson LL 1983 Growth hormone secretion after hypophysial stalk transection in pigs. Proceedings of the Society for Experimental Biology and Medicine 172 508-513.

Klindt J, Yen JT, Buonomo FC, Roberts AJ \& Wise T 1998 Growth, body composition, and endocrine responses to chronic administration of insulin-like growth factor I and(or) porcine growth hormone in pigs. Journal of Animal Science 76 2368-2381.

Laemmli UK 1970 Cleavage of structural proteins during the assembly of the head of bacteriophage T4. Nature 227 680-685.

Lee CY, Lee HP, Jeong JH, Baik KH, Jin SK, Lee JH \& Sohnt SH 2002 Effects of restricted feeding, low-energy diet, and implantation of trenbolone acetate plus estradiol on growth, carcass traits, and circulating concentrations of insulin-like growth factor (IGF)-I and IGF-binding protein-3 in finishing barrows. Journal of Animal Science 80 84-93.

Lindzey J, Wetsel WC, Couse JF, Stoker T, Cooper R \& Korach KS 1998 Effects of castration and chronic steroid treatments on hypothalamic gonadotropin-releasing hormone content and pituitary gonadotropins in male wild-type and estrogen receptor-alpha knockout mice. Endocrinology 139 4092-4101.

Long GG \& Diekman MA 1984 Effect of purified zearalenone on early gestation in gilts. Journal of Animal Science 59 1662-1670.

Mauras N, O’Brien KO, Klein KO \& Hayes V 2000 Estrogen suppression in males: metabolic effects. Journal of Clinical Endocrinology and Metabolism 85 2370-2377.

Mazerbourg S, Overgaard MT, Oxvig C, Christiansen M, Conover CA, Laurendeau I, Vidaud M, Tosser-Klapp G, Zapf J \& Monget P 2001 Pregnancy-associated plasma protien-A (PAPP-A) in ovine, bovine, porcine and equine ovarian follicles: involvement in IGF binding protein- 4 protolytic degredation and mRNA expression during follicular development. Endocrinology 142 5243-5253.

Michels KM, Lee WH, Seltzer A, Saavedra JM \& Bondy CA 1993 Up-regulation of pituitary [125I]insulin-like growth factor-I (IGF-I) binding and IGF binding protein-2 and IGF-I gene expression by estrogen. Endocrinology 132 23-29.

Mohan S \& Baylink DJ 1995 Development of a simple valid method for the complete removal of insulin-like growth factor (IGF)-binding proteins from IGFs in human serum and other biological fluids: comparison with acid-ethanol treatment and C18 Sep-Pak separation. Journal of Clinical Endocrinology and Metabolism 80 637-647.

Murphy LJ \& Friesen HG 1988 Differential effects of estrogen and growth hormone on uterine and hepatic insulin-like growth factor I gene expression in the ovariectomized hypophysectomized rat. Endocrinology 122 325-332.

Murphy LJ, Murphy LC \& Friesen HG 1987 Estrogen induces insulin-like growth factor-I expression in the rat uterus. Molecular Endocrinology 1 445-450.

Nitta H, Bunick D, Hess RA, Janulis L, Newton SC, Millette CF, Osawa Y, Shizuta Y, Toda K \& Bahr JM 1993 Germ cells of the mouse testis express P450 aromatase. Endocrinology 132 1396-1401.
Owens PC, Gatford KL, Walton PE, Morley W \& Campbell RG 1999 The relationship between endogenous insulin-like growth factors and growth in pigs. Journal of Animal Science 77 2098-2103.

Plourde PV, Dyroff M \& Dukes M 1994 Arimidex: a potent and selective fourth-generation aromatase inhibitor. Breast Cancer Research and Treatment 30 103-111.

Rempel LA \& Clapper JA 2002 Administration of estradiol-17 beta increases anterior pituitary IGF-I and relative amounts of serum and anterior pituitary IGF-binding proteins in barrows. Journal of Animal Science 80 214-224.

Richman C, Baylink DJ, Lang K, Dony C \& Mohan S 1999 Recombinant human insulin-like growth factor-binding protein-5 stimulates bone formation parameters in vitro and in vivo. Endocrinology 140 4699-4705.

Simard J, Hubert JF, Hosseinzadeh T \& Labrie F 1986 Stimulation of growth hormone release and synthesis by estrogens in rat anterior pituitary cells in culture. Endocrinology 119 2004-2011.

Simmen RC, Simmen FA, Hofig A, Farmer SJ \& Bazer FW 1990 Hormonal regulation of insulin-like growth factor gene expression in pig uterus. Endocrinology 127 2166-2174.

Simpson ER, Mahendroo MS, Means GD, Kilgore MW, Hinshelwood MM, Graham-Lorence S, Amarneh B, Ito Y, Fisher CR \& Michael MD 1994 Aromatase cytochrome P450, the enzyme responsible for estrogen biosynthesis. Endocrine Reviews 15 342-355.

Slootweg MC, Ohlsson C, Salles JP, de Vries CP \& Netelenbos JC 1995 Insulin-like growth factor binding proteins- 2 and -3 stimulate growth hormone receptor binding and mitogenesis in rat osteosarcoma cells. Endocrinology 136 4210-4217.

Taxel P, Kennedy DG, Fall PM, Willard AK, Clive JM \& Raisz LG 2001 The effect of aromatase inhibition on sex steroids, gonadotropins, and markers of bone turnover in older men. Journal of Clinical Endocrinology and Metabolism 86 2869-2874.

Veldhuis JD \& Iranmanesh A 2005 Short-term aromatase-enzyme blockade unmasks impaired feedback adaptations in luteinizing hormone and testosterone secretion in older men. Journal of Clinical Endocrinology and Metabolism 90 211-218.

Weissberger AJ \& Ho KK 1993 Activation of the somatotropic axis by testosterone in adult males: evidence for the role of aromatization. Journal of Clinical Endocrinology and Metabolism 76 1407-1412.

Yates RA, Dowsett M, Fisher GV, Selen A \& Wyld PJ 1996 Arimidex (ZD1033): a selective, potent inhibitor of aromatase in postmenopausal female volunteers. British Journal of Cancer $\mathbf{7 3}$ $543-548$.

Zapf J 1995 Physiological role of the insulin-like growth factor binding proteins. European Journal of Endocrinology 132 645-654.

Received 24 August 2005

Accepted 2 September 2005

Made available online as an Accepted Preprint 26 September 2005 